\title{
Comparison of Fatty Acid, Protein, and Serological Properties Distinguishing Outer Membranes of Pseudomonas anguilliseptica Strains from Those of Fish Pathogens and Other Pseudomonads
}

\author{
KAZUHIRO NAKAJIMA, ${ }^{1,2}$ KOKOYUNI MUROGA ${ }^{2}$ AND ROBERT E. W. HANCOCK ${ }^{1 *}$ \\ Department of Microbiology, University of British Columbia, Vancouver, British Columbia, Canada V6T \\ $1 W 5^{1}$ and Department of Fisheries, Faculty of Applied Biological Sciences, Hiroshima University, \\ Fukuyama, Japan ${ }^{2}$
}

Whole-cell fatty acid analyses of 79 Pseudomonas anguilliseptica strains demonstrated that all 79 strains were closely related and were distinct from other pseudomonads whose fatty acid profiles were reported previously. Outer membranes were isolated from seven representative strains, and the protein patterns were compared by sodium dodecyl sulfate-polyacrylamide gel electrophoresis. Four major outer membrane proteins were found in each of the $P$. anguilliseptica strains but not in the outer membranes of 8 other Pseudomonas strains or 10 other fish pathogens. The outer membranes of the seven $P$. anguilliseptica strains studied were immunologically cross-reactive. We suggest that outer membrane protein patterns may be a useful taxonomic tool.

Pseudomonas anguilliseptica was first identified in 1972 as the causative agent of red spot disease in cultured Japanese eels (18). Although this name appears on the Approved Lists of Bacterial Names (17), little taxonomic work other than bacteriological characterization studies $(13,18)$ has been performed on this organism.

In this paper we describe studies on the whole-cell fatty acids and on the outer membrane protein patterns and immunological crossreactions of $\boldsymbol{P}$. anguilliseptica strains. Furthermore, we isolated the outer membranes of 9 other Pseudomonas strains and 10 nonpseudomonal fish pathogens. Our results suggest that outer membranes may be useful in determining taxonomic similarities.

\section{MATERIALS AND METHODS}

Bacterial strains and growth conditions. The bacteria which we used are described in Table 1 . Generally, the medium used was $1 \%(\mathrm{wt} / \mathrm{vol})$ proteose peptone no. 2 medium (catalog no. 0121-01; Difco Laboratories, Detroit, Mich.) containing $0.5 \%$ (wt/vol) $\mathrm{NaCl}$. In control experiments we determined that this medium allowed optimum growth of $P$. anguilliseptica and Pseudomonas aeruginosa strains and excellent growth of all of the other bacteria used. The doubling time of $P$. anguilliseptica ET7601 was $4.4 \mathrm{~h}$ at $20^{\circ} \mathrm{C}$, whereas the maximal attainable values of adsorbance at $600 \mathrm{~nm}$ were about 1.7 . Occasionally, the medium was supplemented with 0.5 to $1 \%$ (wt/vol) RILA marine salts mixture (Rila Products, Teaneck, N.J.). All cells were grown at $20^{\circ} \mathrm{C}$ with shaking and were harvested during the mid-logarithmic phase of growth (absorbance at $600 \mathrm{~nm}, 0.6$ to 0.8 ). The solid medium used consisted of $1 \%(\mathrm{wt} / \mathrm{vol})$ proteose peptone no. 2 medium, $0.5 \%$ (wt/vol) $\mathrm{NaCl}$, and $2 \%$ (wt/vol) agar (Difco).

Whole-cell fatty acid analysis. Whole-cell fatty acids (both lipopolysaccharide- and lipid-associated fatty acids) were analyzed after transmethylation by gasliquid chromatography, as previously described by Kropinski et al. (11). Peaks were identified by comparison with a standard bacterial fatty acid mixture obtained from Supelco Ltd., Bellefonte, Pa. Pentadecanoic acid was used as an internal standard to assist quantitation; control experiments were performed to detect pentadecanoic acid in individual cells.

Outer membrane isolation and SDS-polyacrylamide gel electrophoresis. Outer membranes were routinely isolated by the method described by Hancock and Nikaido (7) for the isolation of $\boldsymbol{P}$. aeruginosa outer membranes. From three to six bands were present on each four-step sucrose gradient. Generally, only the uppermost band had properties of inner membranes (i.e., high succinate dehydrogenase levels, relatively low 2-keto-3-deoxyoctulosonic acid levels, and little or none of the major outer membrane protein observed in the denser bands). The two to five lower bands were identified as outer membranes based on their high 2keto-3-deoxyoctulosonic acid levels (1.2 to $5.3 \mu \mathrm{g} / \mathrm{mg}$ of protein), low succinate dehydrogenase levels $(<0.1$ $\mu \mathrm{mol}$ of dichloroindolephenol reduced per min per $\mathrm{mg}$ of protein), and characteristic protein patterns (7). Sodium dodecyl sulfate (SDS)-polyacrylamide gel electrophoresis was performed as previously described (6); a $14 \%$ running gel containing $0.07 \mathrm{M} \mathrm{NaCl}$ was used.

Antigenicity of outer membranes. Outer membranes (50 $\mu \mathrm{g}$ of protein) from $P$. anguilliseptica strains ET7601 and ET2 were separately injected subcutaneously into DBA mice (Jackson Laboratories, Bar Harbor, Maine). After 2 and 4 weeks, the mice were given subcutaneous booster injections containing 10 
TABLE 1. Bacterial strains used in this study ${ }^{a}$

\begin{tabular}{|c|c|c|}
\hline Species & Strain & Source \\
\hline \multirow[t]{8}{*}{$P$. anguilliseptica } & NCMB $1949^{T}$ & Japanese eel \\
\hline & NCMB 1950 & Japanese eel \\
\hline & ET7601 & Japanese eel \\
\hline & ET2 & Japanese eel \\
\hline & S1 & Japanese eel \\
\hline & SE1 & Japanese eel \\
\hline & NE2 & Japanese eel \\
\hline & ME1 & Japanese eel \\
\hline \multirow[t]{2}{*}{ P. fluorescens } & $\operatorname{ATCC} 13525^{\mathrm{T}}$ & Prefilter water works tanks \\
\hline & ATCC 949 & Creamery waste \\
\hline \multirow[t]{3}{*}{$P$. aeruginosa } & PAO1 & Human isolate (originally designated \\
\hline & ATCC 8689 & P. fluorescens) \\
\hline & ATCC 9721 & $\begin{array}{l}\text { (originally designated } \\
P \text {. fluorescens) }\end{array}$ \\
\hline \multirow[t]{2}{*}{ P. putida } & ATCC $12633^{\mathrm{T}}$ & Soil \\
\hline & K4359 & Soil \\
\hline P. acidovorans & ATCC 9355 & Soil \\
\hline Pseudomonas sp. & BS-3 & Black seabream \\
\hline \multirow{2}{*}{ Aeromonas salmonicida } & NCMB 1102 & Salmon \\
\hline & NCMB 2020 & Japanese salmon \\
\hline Aeromonas hydrophila & ET2 & Eel \\
\hline Edwardsiella tarda & ET79054 & Eel \\
\hline \multirow[t]{3}{*}{ Vibrio anguillarum } & ET208 & Eel \\
\hline & PB15 & Ayu \\
\hline & HT7602 & Yellowtail \\
\hline \multirow[t]{2}{*}{ "Vibrio anguillicida" } & ET517 & Eel \\
\hline & ATCC 33149 & Eel \\
\hline Vibrio cholerae (non O-I) & PS7910 & Ayu \\
\hline
\end{tabular}

${ }^{a}$ All strains were characterized by using standard biochemical tests $(13,14,18)$.

$\mu \mathrm{g}$ of outer membrane protein, and 7 days after the third injection the mice were bled through the tail. The sera from these blood samples were diluted and tested by an enzyme-linked immunosorbent assay (1) for antibodies to outer membranes; outer membranes were used as the coating antigen, and alkaline phosphatase-linked rabbit anti-mouse immunoglobulin was used as the second antibody. The results were recorded with a Titertek Multiscan spectrophotometer (Flow Laboratories, Inglewood, Calif.) $30 \mathrm{~min}$ after paranitrophenyl phosphate was added. Serum from uninjected DBA mice was used as a control.

\section{RESULTS}

Fatty acid composition of $\boldsymbol{P}$. anguilliseptica. To determine whether the strains of $\boldsymbol{P}$. anguilliseptica isolated to date represented a single taxonomic species, we determined the whole-cell fatty acid compositions of 79 strains (Table 2) which previously had demonstrated a large degree of similarity in biochemical tests (13). The utility of whole-cell fatty acid composition for differentiating Pseudomonas strains has been clearly demonstrated by Moss and his colleagues $(3,10,12)$. The data in Table 2 strongly suggested that $P$. anguilliseptica represents a single taxonomic species.

Isolation of the outer membrane of $P$. anguilliseptica and properties of the outer membrane proteins. Fractionation of $\boldsymbol{P}$. anguilliseptica cell envelopes on a sucrose density step gradient produced outer membrane bands having different densities but very similar protein compositions (Fig. 1).

A comparison of the outer membrane protein compositions of seven $P$. anguilliseptica strains revealed striking similarities in protein composition with respect to both major and minor proteins (Fig. 2 and Table 3). However, the differences were large enough to suggest that these individual isolates were not genetically identical.

The properties of the individual outer membrane proteins were studied by changing the solubilization conditions before SDS-polyacrylamide gel electrophoresis. The apparent molecular weights of two proteins were influenced by the temperature of solubilization before gel electrophoresis. One protein, the $36.5 \mathrm{~K}$ protein, which was found only in strain ET2, had apparent molecular weights of 34,500 after solubilization at $37^{\circ} \mathrm{C}$ and 36,500 after solubilization at $88^{\circ} \mathrm{C}$. Another protein, the $22 \mathrm{~K}$ protein, which was found in the other six strains (strains NCMB $1949^{\mathrm{T}}$ [type strain], NCMB 1950, ET7601, SE1, ME1, and NE2) but not in strain ET2, was also heat modifiable. This protein co-electrophoresed with the $19 \mathrm{~K}$ protein (apparent molecular weight, 19,000) after solubilization at $37^{\circ} \mathrm{C}$, whereas it had an apparent molecular weight of 
22,500 after solubilization at $88^{\circ} \mathrm{C}$. Heat modification of the $22 \mathrm{~K}$ and $36.5 \mathrm{~K}$ proteins was inhibited by the presence of $0.1 \mathrm{M} \mathrm{Mg}^{2+}$ in the solubilization mixture. Under such conditions, after solubilization at $88^{\circ} \mathrm{C}$ both the heat-modified (higher-molecular-weight) forms and the heat-unmodified (lower-molecular-weight) forms of these proteins were observed together in the gel. Similar behavior has been observed for major outer membrane protein $\mathrm{G}$ of $P$. aeruginosa (6) and for protein II* of Escherichia coli K-12 (15).

The appearance of the $12 \mathrm{~K}$ protein in gels was influenced in most strains by the presence of ethylenediaminetetraacetate or $\mathbf{M g}^{2+}$ in the solubilization mixture. $\mathrm{Mg}^{2+}$ favored the appearance of this protein, whereas ethylenediaminetetraacetate inhibited its appearance. Similar results have been obtained for a Braun type of outer membrane lipoprotein (protein I) of $\boldsymbol{P}$. aeruginosa and have been shown to result from the influence of ethylenediaminetetraacetate and $\mathrm{Mg}^{2+}$ on the migration of lipopolysaccharide (which can mask this lipoprotein) in gels $(6,11)$.

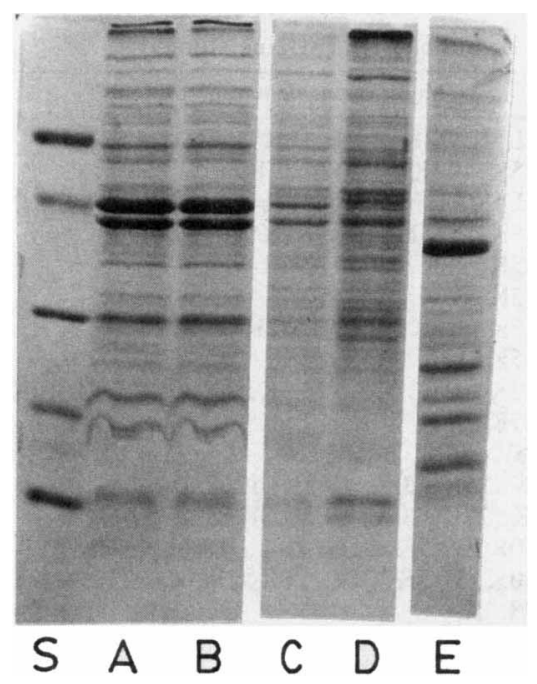

FIG. 1. SDS-polyacrylamide gel electrophoretograms of membrane bands from step sucrose density gradient separation of $P$. anguilliseptica strain ET7601 cell envelopes. Gels A, B, C, and D show the protein compositions of the bands at the interfaces of the original 70 to $64 \%$ sucrose step (OM1 band [9]), the 64 to $58 \%$ sucrose step (OM2 band), the 58 to $52 \%$ sucrose step ( $M$ band), and the 52 to $44 \%$ sucrose step (IM band), respectively. In gel E the OM2 band of $P$. aeruginosa PAO1 (7) is shown for comparison. The molecular weights of the major outer membrane protein bands were estimated by comparison with a series of molecular weight standards (gel S), including bovine serum albumin (molecular weight, 66,200), ovalbumin $(45,000)$, carbonic anhydrase $(31,000)$, trypsin inhibitor $(21,500)$, and lysozyme $(14,400)$.

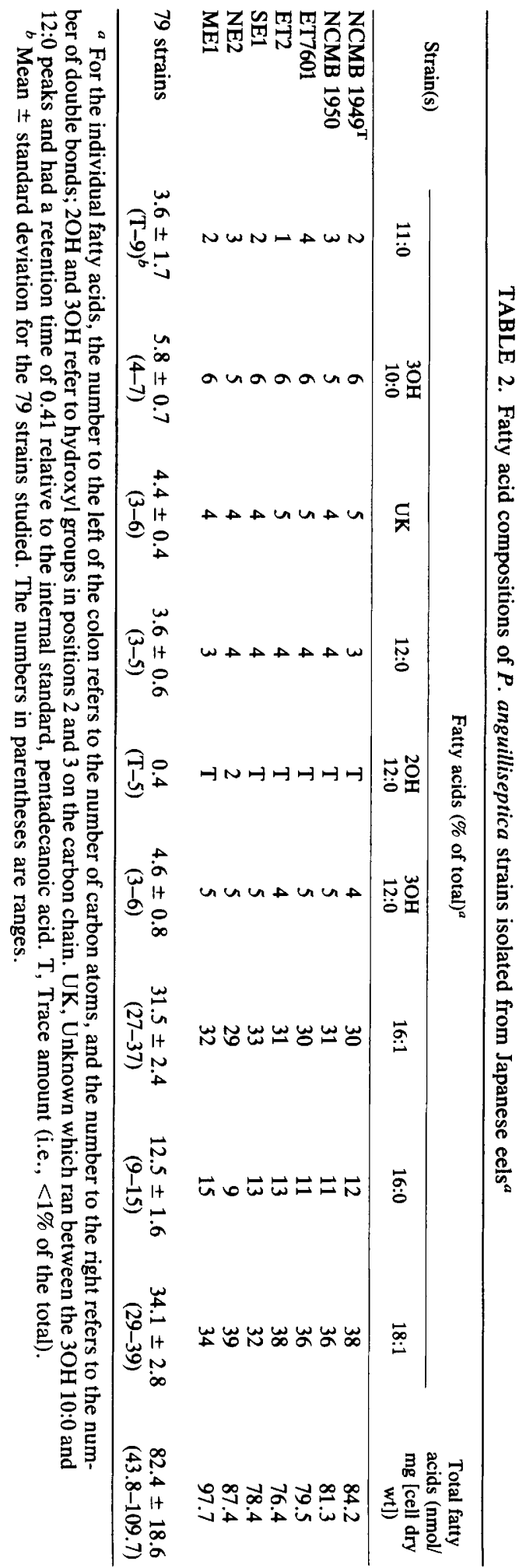




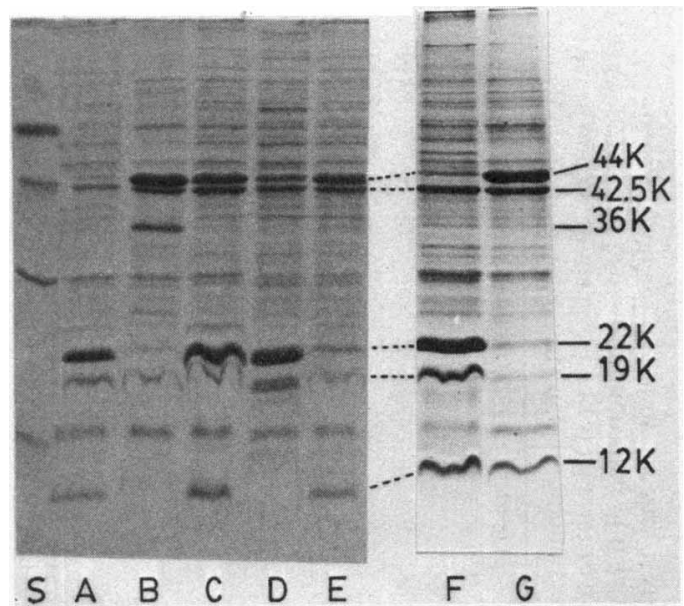

FIG. 2. SDS-polyacrylamide gel electrophoretograms of the outer membranes (OM1 on OM2 bands [see Fig. 1]) of $P$. anguilliseptica strains ET7601 (gel A), ET2 (gel B), SE1 (gel C), NE2 (gel D), ME1 (gel E), NCMB $1949^{\mathrm{T}}$ (gel F), and NCMB 1950 (gel G). Gel $S$ contained standards (see the legend to Fig. 1).
In addition to altering the solubilization conditions, we also isolated outer membranes from strain ET7601 grown with a variety of salt supplements. This strain (as well as strain NCMB $1949^{\mathrm{T}}$ ) had far lower levels of the $44 \mathrm{~K}$ protein in its outer membrane (Fig. 2) than other strains when they were grown under our standard conditions (proteose peptone no. 2 medium containing $0.5 \% \mathrm{NaCl}$ ). However, omission of saline from proteose peptone no. 2 medium resulted in production of the $44 \mathrm{~K}$ protein at levels equal to those present in other $P$. anguilliseptica strains (Fig. 3, gel B). The presence of $0.5 \%$ marine salts in the medium prevented the suppression of $44 \mathrm{~K}$ protein production by $0.5 \% \mathrm{NaCl}$ (Fig. 3, gels $\mathrm{G}$ and $\mathrm{C}$ ), whereas even $1 \%$ marine salts did not suppress the appearance of this protein (Fig. 3 , gel I). The concentration of $\mathrm{NaCl}$ in the medium apparently influenced the appearance in the gel of at least one other protein. A minor 31,000 -dalton protein $(31 \mathrm{~K}$ protein) appeared at its greatest concentration in cells grown on $1 \%$ $\mathrm{NaCl}$ (Fig. 3, gel D).

TABLE 3. Major outer membrane proteins of the bacterial strains studied ${ }^{a}$

\begin{tabular}{|c|c|c|}
\hline Species & Strain & Major outer membrane proteins \\
\hline P. anguilliseptica & $\begin{array}{l}\text { NCMB } 1949^{\mathrm{T}} \\
\text { NCMB } 1950 \\
\text { ET7601 } \\
\text { ET2 } \\
\text { SE1 } \\
\text { NE2 } \\
\text { ME1 }\end{array}$ & $\begin{array}{l}(44 \mathrm{~K}), 42.5 \mathrm{~K}, 22 \mathrm{~K}, 19 \mathrm{~K}, 12 \mathrm{~K}^{\mathrm{b}} \\
44 \mathrm{~K}, 42.5 \mathrm{~K},(22 \mathrm{~K}),(19 \mathrm{~K}), 12 \mathrm{~K} \\
(44 \mathrm{~K}), 42.5 \mathrm{~K}, 22 \mathrm{~K}, 19 \mathrm{~K}, 12 \mathrm{~K}^{c} \\
44 \mathrm{~K}, 42.5 \mathrm{~K}, 36.5 \mathrm{~K}, 19 \mathrm{~K}, 12 \mathrm{~K}^{c} \\
44 \mathrm{~K}, 42.5 \mathrm{~K}, 22 \mathrm{~K}, 19 \mathrm{~K}, 12 \mathrm{~K} \\
44 \mathrm{~K}, 42.5 \mathrm{~K}, 22 \mathrm{~K}, 19 \mathrm{~K}, 12 \mathrm{~K}^{c} \\
44 \mathrm{~K}, 42.5 \mathrm{~K},(22 \mathrm{~K}),(19 \mathrm{~K}), 12 \mathrm{~K}\end{array}$ \\
\hline Pseudomonas sp. & BS-3 & $44 \mathrm{~K}, 42.5 \mathrm{~K}, 12 \mathrm{~K}$ \\
\hline P. fluorescens & $\begin{array}{l}\text { ATCC } 13525^{\mathrm{T}} \\
\text { ATCC } 949\end{array}$ & $\begin{array}{l}43.5 \mathrm{~K}, 42 \mathrm{~K}, 41 \mathrm{~K}, 33 \mathrm{~K}, 25.5 \mathrm{~K}, 20 \mathrm{~K},(19.5 \mathrm{~K}), 12 \mathrm{~K} \\
41 \mathrm{~K}, 33.5 \mathrm{~K}, 25 \mathrm{~K}, 20 \mathrm{~K}, 19.5 \mathrm{~K}, 12 \mathrm{~K}\end{array}$ \\
\hline$P$. aeruginosa & $\begin{array}{l}\text { PAO1 } \\
\text { ATCC } 8689 \\
\text { ATCC } 9721\end{array}$ & $\begin{array}{l}(42 \mathrm{~K}), 38 \mathrm{~K}, 25 \mathrm{~K}, 20 \mathrm{~K}, 12 \mathrm{~K}^{c} \\
42 \mathrm{~K}, 38 \mathrm{~K}, 25 \mathrm{~K}, 20 \mathrm{~K}, 18.5 \mathrm{~K}, 12 \mathrm{~K}^{d} \\
42 \mathrm{~K}, 38 \mathrm{~K}, 25 \mathrm{~K}, 20 \mathrm{~K}, 18.5 \mathrm{~K}, 12 \mathrm{~K}^{d}\end{array}$ \\
\hline P. putida & $\begin{array}{l}\text { ATCC } 12633^{\mathrm{T}} \\
\text { K4359 }\end{array}$ & $\begin{array}{l}41.5 \mathrm{~K}, 40 \mathrm{~K}, 37.5 \mathrm{~K}, 21 \mathrm{~K}, 20 \mathrm{~K},(18.5 \mathrm{~K}), 12 \mathrm{~K} \\
41.5 \mathrm{~K}, 40 \mathrm{~K}, 37.5 \mathrm{~K}, 21 \mathrm{~K}, 20 \mathrm{~K}, 18.5 \mathrm{~K}, 12 \mathrm{~K}\end{array}$ \\
\hline$P$. acidovorans & ATCC 9355 & $33.5 \mathrm{~K}, 28.5 \mathrm{~K}$ \\
\hline Aeromonas salmonicida & $\begin{array}{l}\text { NCMB } 1102 \\
\text { NCMB } 2020\end{array}$ & $\begin{array}{l}44 \mathrm{~K}, 40 \mathrm{~K},(37.5 \mathrm{~K}), 30 \mathrm{~K}, 29 \mathrm{~K}, 12.5 \mathrm{~K} \\
44 \mathrm{~K}, 40 \mathrm{~K},(37.5 \mathrm{~K}), 30 \mathrm{~K}, 29 \mathrm{~K}, 12.5 \mathrm{~K}\end{array}$ \\
\hline Aeromonas hydrophila & ET-2 & $45 \mathrm{~K}, 40 \mathrm{~K}, 37.5 \mathrm{~K}, 28.5 \mathrm{~K}, 24 \mathrm{~K}, 22.5 \mathrm{~K}, 12 \mathrm{~K}$ \\
\hline Edwardsiella tarda & ET79054 & $41 \mathrm{~K}, 38 \mathrm{~K}, 32 \mathrm{~K}, 12.5 \mathrm{~K}$ \\
\hline Vibrio anguillarum & $\begin{array}{l}\text { ET208 } \\
\text { PB15 } \\
\text { HT7602 }\end{array}$ & $\begin{array}{l}33.5 \mathrm{~K} \\
36 \mathrm{~K}, 27 \mathrm{~K} \\
45 \mathrm{~K}, 37 \mathrm{~K}, 27 \mathrm{~K}\end{array}$ \\
\hline "Vibrio anguillicida" & $\begin{array}{l}\text { ET517 } \\
\text { ATCC } 33149\end{array}$ & $\begin{array}{l}44 \mathrm{~K}, 35 \mathrm{~K},(27.5 \mathrm{~K}) \\
44 \mathrm{~K}, 42 \mathrm{~K}, 35 \mathrm{~K}, 27.5 \mathrm{~K}\end{array}$ \\
\hline Vibrio cholerae (non $0-\mathrm{I}$ ) & PS7910 & $39.5 \mathrm{~K}, 33.5 \mathrm{~K}, 27.5 \mathrm{~K}$ \\
\hline
\end{tabular}

${ }^{a}$ A major protein that comigrated with lysozyme (the $14.4 \mathrm{~K}$ protein) has been omitted from this table since it may represent contaminating lysozyme which bound to the outer membranes.

${ }^{b}$ The proteins in parentheses are proteins with less dense bands corresponding to the major bands of related bacterial strains.

${ }^{c}$ The $12 \mathrm{~K}$ protein was observed in SDS-polyacrylamide gels only after solubilization of the outer membranes in the presence of $\mathrm{Mg}^{2+}$.

${ }^{d}$ The $18.5 \mathrm{~K}$ protein was probably the heat-unmodified form of the $25 \mathrm{~K}$ protein (6). 


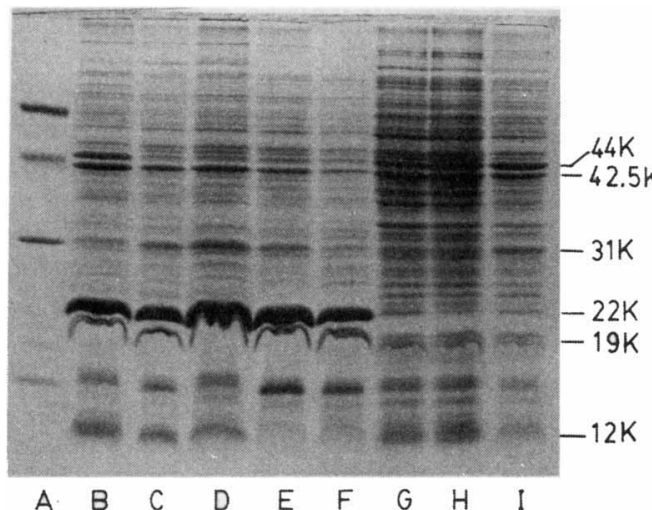

FIG. 3. SDS-polyacrylamide gel electrophoretograms of outer membranes isolated after growth of $\boldsymbol{P}$. anguilliseptica strain ET7601 on proteose peptone no. 2 medium containing the following salt supplements: gel $\mathrm{B}$, no salt supplement; gel C, $0.5 \%$ (wt/vol) $\mathrm{NaCl}$; gel $\mathrm{D}, 1 \%$ (wt/vol) $\mathrm{NaCl}$; gel E, $2 \%$ (wt/vol) $\mathrm{NaCl}$; gel F, 3\% (wt/vol) NaCl; gel G, $0.5 \%$ (wt/vol) $\mathrm{NaCl}$ and $0.5 \%$ (wt/vol) marine salts mixture; gel $\mathrm{H}, 0.5 \%$ (wt/vol) marine salts mixture; gel I, $1 \%$ (wt/vol) marine salts mixture. Gel A contained standards (see the legend to Fig. 1).

The inclusion of marine salts in the growth medium had two other effects. First, it resulted in considerably poorer separation of the outer and inner membranes of $P$. anguilliseptica strain ET7601; and second, it resulted in loss of the $22 \mathrm{~K}$ protein, the major outer membrane polypeptide band of strain ET7601 (Fig. 3, gels G through I).

Comparison with other strains. Outer membranes were isolated from six other species of fish pathogens and five other species of the genus Pseudomonas. Examples of separations of these membranes are shown in Fig. 4. In each case excellent separation was achieved, as determined by assays of an outer membrane marker (2-keto-3-deoxyoctulosonic acid) and of an inner membrane marker (succinate dehydrogenase) (data not shown) and by the protein patterns after SDS-polyacrylamide gel electrophoresis (Fig. 4). The outer membrane protein patterns of all of the strains are shown in Fig. 5, and the patterns of major outer membrane proteins are summarized in Table 3 . Our results suggest that there are not only large differences in outer membrane protein patterns among species within the same genus but also marked similarities within a species (see below).

Immunological cross-reaction of outer membranes. To obtain further evidence for the relatedness of $\boldsymbol{P}$. anguilliseptica strains, we produced antibodies in mice against the whole outer membranes of strains ET7601 and ET2. Sera raised against strain ET7601 outer membranes reacted strongly with the outer membranes from the other six $P$. anguilliseptica strains and from Pseudomonas sp. strain BS-3 (Table 4) and 10to 40 -fold less with $P$. aeruginosa PAO1, Pseudomonas fluorescens ATCC $13525^{\mathrm{T}}$, and Pseudomonas putida ATCC $12633^{\mathrm{T}}$ outer membranes. All other outer membranes reacted weakly with anti-ET7601 outer membrane serum (Table 4). There was no measurable reaction with normal mouse serum.

The results with antisera directed against strain ET2 outer membranes were somewhat different. The strongest reactions were with the
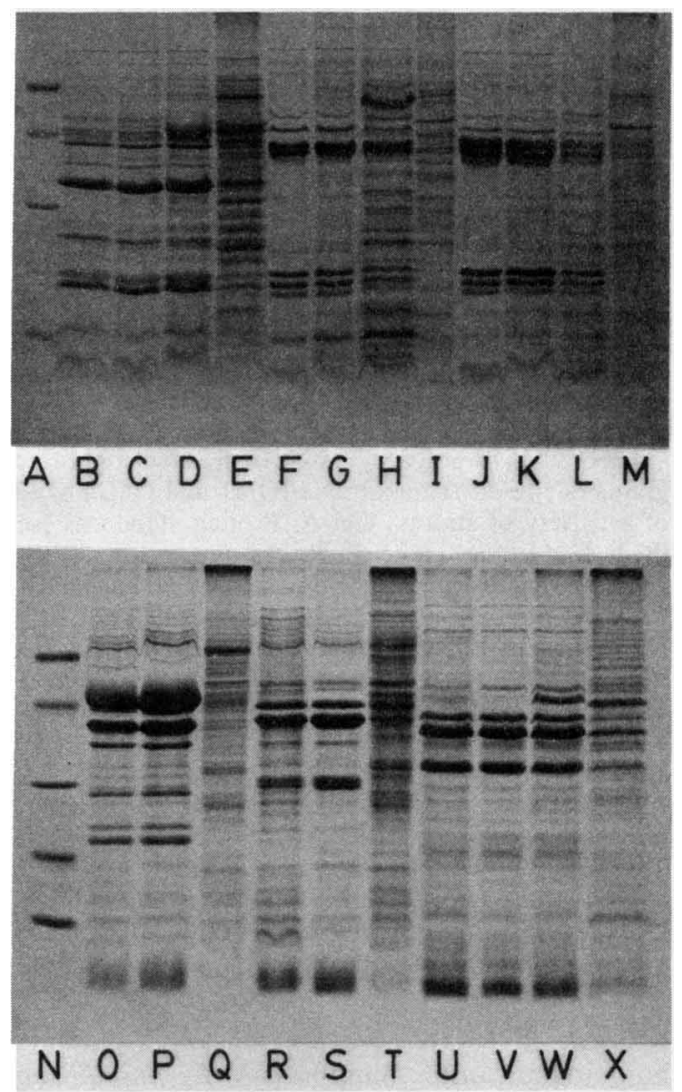

FIG. 4. SDS-polyacrylamide gel electrophoretograms of bands from step sucrose density gradient separation of cell envelopes from $P$. fluorescens ATCC $13525^{\mathrm{T}}$ (gels B through E), $P$. putida K4359 (gels F through I), $P$. putida ATCC $12633^{\mathrm{T}}$ (gels J through M), Aeromonas hydrophila ET2 (gels O through Q); Aeromonas salmonicida NCMB 1102 (gels $\mathrm{R}$ through T), and Edwardsiella tarda ET79054 (gels U through X). By analogy with previously described separations (9) and those described in the legend to Fig. 1, the gels represent OM1 (gels B, F, J, O, R, and U), OM2 (gels C, G, K, P, S, and V), M (gels D, H, L, and $W$ ), and IM (gels E, I, M, Q, T, and X) bands. Gels $\mathrm{A}$ and $\mathrm{N}$ contained standard proteins, as described in the legend to Fig. 1. 


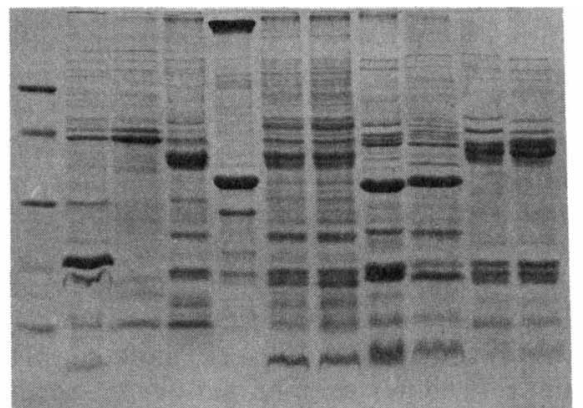

A B C D E F G H I J K
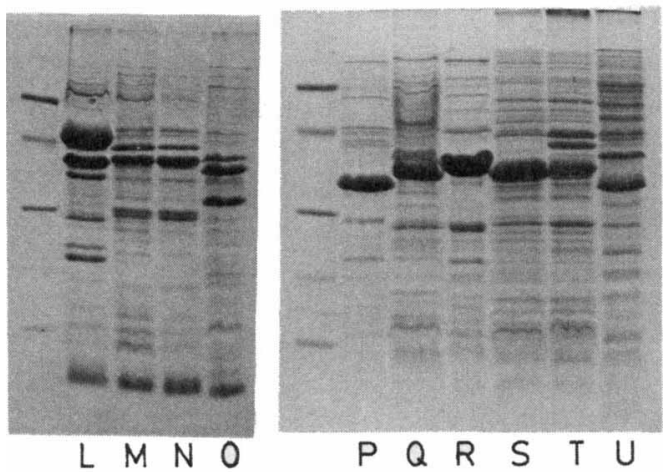

FIG. 5. SDS-polyacrylamide gel electrophoretograms of the outer membrane (OM1 and OM2) bands of a variety of strains. Gel A, Protein standards (see the legend to Fig. 1); gel B, P. anguilliseptica ET7601; gel C, Pseudomonas sp. BS-3; gel D, $P$. aeruginosa PAO1; gel E, $P$. acidovorans ATCC 9355; gel F, $P$. aeruginosa ATCC 8689; gel G, $P$. aeruginosa ATCC 9721; gel H, $P$. fluorescens ATCC 949; gel I, $P$. fuorescens ATCC $13525^{\mathrm{T}}$; gel J, $P$. putida K4359; gel K, $P$. putida ATCC $12633^{\mathrm{T}}$; gel L, Aeromonas hydrophila ET2; gel M, Aeromonas salmonicida NCMB 1102; gel N, A. salmonicida NCMB 2020; gel O, Edwardsiella tarda ET79054; gel P, Vibrio anguillarum ET208; gel Q, $V$. anguillarum PB15; gel $\mathrm{R}, V$. anguillarum HT7602; gel S, "Vibrio anguillicida", ET517; gel T, "V. anguillicida"' ATCC 33149; gel U, Vibrio cholerae (non O-I) PS7910.

homologous outer membranes, $P$. anguilliseptica SE1 outer membranes, and $P$. Aluorescens ATCC $13525^{\mathrm{T}}$ outer membranes (Table 4). The reactions of all other pseudomonad outer membranes tested except $P$. aeruginosa PAO1 and Pseudomonas acidovorans ATCC 9355 outer membranes were 13- to 20-fold weaker. These results suggest that strain ET2 outer membranes contain an immunodominant antigen which is not shared by the other $P$. anguilliseptica strains studied.

\section{DISCUSSION}

Our results suggest that outer membrane protein patterns might provide a useful adjunct for indicating genetic similarities and differences within a single species.

A fatty acid analysis of $79 P$. anguilliseptica strains strongly indicated that these strains were related and could be differentiated from other $P$ seudomonas species, including $P$. acidovorans (12), $P$. aeruginosa $(11,12), P$. alcaligenes (3), $P$. diminuta (19), $P$. maltophilia (12), $P$. pseudoalcaligenes (3), $P$. putida (12), " $P$. putrefaciens" (3), P. stutzeri (19), "P. syncyanea" (19), and $P$. testosteroni (12). The most closely related strains on the basis of fatty acid composition were those of $P$. aeruginosa, $P$. putida, and " $P$. syncyanea;" each of these taxa had seven major fatty acid peaks in common with $P$. anguilliseptica, including all of the fatty acids $(\mathrm{C} 12: 0,3 \mathrm{OH}$

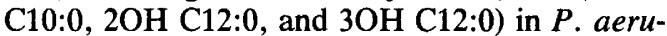
ginosa and " $P$. syncyanea" which are found exclusively in the lipopolysaccharide $(11,19)$. However, fatty acid composition alone is of limited taxonomic use, since, for example, the fatty acid compositions of $P$. fluorescens (2) and $P$. aeruginosa (Nakajima and Hancock, unpublished data) can vary substantially with growth temperature and the appearance of at least one group of fatty acids, the cyclopropanes, is related to the phase of growth during which the bacteria are harvested $(2,5)$.

We also produced antisera against the outer membranes of two different $P$. anguilliseptica strains. When antiserum against strain ET7601 outer membranes was tested (Table 4), the outer membranes of each of the six $P$. anguilliseptica strains and Pseudomonas sp. strain BS-3 reacted as well as strain ET7601 outer membranes, suggesting that these outer membranes shared antigens. However, when antiserum against strain ET2 outer membranes was used, the outer membranes of other $P$. anguilliseptica strains showed enzyme-linked immunosorbent assay titers which were no greater than those of some other Pseudomonas species (Table 4). Thus, the usefulness of antigenic relationships in demonstrating the taxonomic relationships among $P$. anguilliseptica strains depends largely upon the antigen used to produce the antiserum. This antigenic specificity is probably due to the lipopolysaccharide, which is generally the immunodominant antigen in gram-negative bacteria and can vary widely within a species. Unfortunately, we were not able to isolate significant quantities of lipopolysaccharide from $P$. anguilliseptica strains by classical techniques, and thus we can shed no further light on the antigenic relationships of the strains within this species or among species in the genus. In contrast, using monoclonal antibody MA1-6, we have recently demonstrated the presence of a common outer membrane protein antigen in $P$. aeruginosa (protein H2), $P$. fluorescens, $P$. putida, Azotobacter vin- 
TABLE 4. Enzyme-linked immunosorbent assay of outer membranes using antisera raised against the outer membranes of $P$. anguilliseptica strains ET7601 and ET2

\begin{tabular}{|c|c|c|c|}
\hline \multicolumn{2}{|c|}{ Outer membrane antigens from: } & \multicolumn{2}{|c|}{ Titer $^{a}$} \\
\hline Species & Strain & $\begin{array}{c}\text { Anti-ET7601 } \\
\text { outer membrane }\end{array}$ & $\begin{array}{c}\text { Anti-ET2 } \\
\text { outer membrane }\end{array}$ \\
\hline \multirow[t]{7}{*}{$P$. anguilliseptica } & NCMB $1949^{\mathrm{T}}$ & $4.2 \times 10^{3}$ & $9.5 \times 10^{2}$ \\
\hline & NCMB 1950 & $4.1 \times 10^{3}$ & $1.0 \times 10^{3}$ \\
\hline & ET7601 & $4.5 \times 10^{3}$ & $4.4 \times 10^{2}$ \\
\hline & ET2 & $3.7 \times 10^{3}$ & $8.2 \times 10^{3}$ \\
\hline & SE1 & $1.2 \times 10^{4}$ & $1.6 \times 10^{3}$ \\
\hline & NE2 & $5.5 \times 10^{3}$ & $6.4 \times 10^{2}$ \\
\hline & ME1 & $8.5 \times 10^{3}$ & $6.0 \times 10^{2}$ \\
\hline Pseudomonas sp. & BS-3 & $3.0 \times 10^{3}$ & $5.0 \times 10^{2}$ \\
\hline \multirow[t]{3}{*}{$P$. aeruginosa } & PAO1 & $3.0 \times 10^{2}$ & $\leqq 10^{1}$ \\
\hline & ATCC 8689 & $8 \times 10^{1}$ & $4.0 \times 10^{2}$ \\
\hline & ATCC 9721 & $3 \times 10^{1}$ & $4.8 \times 10^{2}$ \\
\hline \multirow[t]{2}{*}{ P. fluorescens } & $\operatorname{ATCC} 1325^{\mathrm{T}}$ & $1.6 \times 10^{2}$ & $3.2 \times 10^{3}$ \\
\hline & ATCC 949 & $\leqq 10^{1}$ & $4.2 \times 10^{2}$ \\
\hline \multirow[t]{2}{*}{ P. putida } & ATCC $12633^{\mathrm{T}}$ & $1.0 \times 10^{2}$ & $6.4 \times 10^{2}$ \\
\hline & K4359 & $5 \times 10^{1}$ & $4.4 \times 10^{2}$ \\
\hline P. acidovorans & ATCC 9355 & $\leqq 10^{1}$ & $\leqq 10^{1}$ \\
\hline Aeromonas hydrophila & ET2 & $\leqq 10^{1}$ & $\leqq 10^{1}$ \\
\hline \multirow[t]{2}{*}{ Aeromonas salmonicida } & NCMB 1102 & $\leqq 10^{1}$ & $\leqq 10^{1}$ \\
\hline & NCMB 2020 & $\leqq 10^{1}$ & $\leqq 10^{1}$ \\
\hline Edwardsiella tarda & ET79054 & $7.5 \times 10^{1}$ & $\leqq 10^{1}$ \\
\hline \multirow[t]{3}{*}{ Vibrio anguillarum } & ET208 & $\leqq 10^{1}$ & $\leqq 10^{1}$ \\
\hline & PB15 & $\leqq 10^{1}$ & $\leqq 10^{1}$ \\
\hline & HT7602 & $\leqq 10^{1}$ & $\leqq 10^{1}$ \\
\hline \multirow[t]{2}{*}{ "Vibrio anguillicida" } & ET517 & $5 \times 10^{1}$ & $\leqq 10^{3}$ \\
\hline & ATCC 33149 & $5 \times 10^{1}$ & $\leqq 10^{1}$ \\
\hline Vibrio cholerae (non $0-\mathrm{I}$ ) & PS7910 & $1.1 \times 10^{2}$ & $\leqq 10^{1}$ \\
\hline
\end{tabular}

${ }^{a}$ Titers (from an enzyme-linked immunosorbent assay) represent the reciprocal of the dilution of antiserum that resulted in $30 \%$ of the value for absorbance at $490 \mathrm{~nm}$ obtained for a $10^{-2}$ dilution of each antiserum (e.g., anti-ET2 outer membrane) when the equivalent outer membrane (e.g., ET2 outer membrane) was used as the antigen.

elandii, and $P$. anguilliseptica, which is not present in the outer membranes of the other strains described here (8).

The data in Table 4 suggest that there are at least two serological groups of $P$. anguilliseptica strains, in agreement with the previous data obtained by using heat- or Formalin-killed cells to produce antisera (14). These data suggest that the basis for differentiating type I (typified by strain ET7601) and type II (typified by strain ET2) $P$. anguilliseptica strains may be more complex than previously suggested (14).

The outer membrane protein patterns further demonstrated that the $P$. anguilliseptica strains were closely related in that five major proteins were observed in most strains under the appropriate growth and solubilization conditions. The major difference was that the $22 \mathrm{~K}$ protein (a heat-modifiable major outer membrane protein) found in the other six strains studied was not found in strain ET2. Instead, the $36.5 \mathrm{~K}$ protein (a heat-modifiable outer membrane protein) was uniquely present in this strain. We cannot say whether these heat-modifiable proteins are re- sponsible for the serological differences discussed above. The $22 \mathrm{~K}$ protein was present in quite different amounts in the six strains containing this protein, and it could be completely suppressed by the presence of a crude marine salts mixture in the growth medium (Fig. 3). Together with the serological relationship noted above, the presence in Pseudomonas sp. strain BS-3 of three major outer membrane protein bands having molecular weights similar or identical to those of $\boldsymbol{P}$. anguilliseptica major outer membrane proteins suggests that this strain should also be classified as a member of $\boldsymbol{P}$. anguilliseptica despite its different origin (Table 1).

Thus, outer membrane protein patterns appear to be useful for showing the similarity among $P$. anguilliseptica strains, and these patterns are clearly different from those of other species, as shown in Table 3 and Fig. 4. One indication of the usefulness of this technique is illustrated by Pseudomonas strains ATCC 8689 and ATCC 9721. These strains were preserved in our departmental collection for many years as 
strains of $P$. fluorescens. However, the outer membrane protein patterns of these strains were very similar to the outer membrane pattern of our standard laboratory $P$. aeruginosa strain PAO1. Upon investigation, we found that these strains were originally isolated and presented to the American Type Culture Collection as $P$. fluorescens strains and were later reclassified as $P$. aeruginosa strains. We have investigated representative strains from all 17 serological types of $\boldsymbol{P}$. aeruginosa and have found that the major outer membrane protein patterns are very similar to those shown in Fig. 4 and Table 3 (L. M. Mutharia, T. I. Nicas, R. E. W. Hancock, J. Infect. Dis., in press) for P. aeruginosa H103. The two $P$. putida strains which we studied are related to one another on the basis of outer membrane protein patterns, as are the two $P$. fluorescens, two Aeromonas salmonicida, and two Vibrio spp. strains studied (Table 3).

It seems likely that major outer membrane proteins are strongly conserved within a species. However, limitations on the use of major outer membrane protein patterns in taxonomy should be noted. For example, of the three strains identified as Vibrio anguillarum on the basis of biochemical tests, strain ET208 was clearly different from the other two (Table 3). In addition, extensive studies on $E$. coli outer membrane proteins have shown small but significant differences in the major outer membrane proteins of some strains, with up to 36 different patterns (15). However, two proteins having slightly different molecular weights from two strains of $E$. coli frequently cross-react immunologically (9).

It has been suggested recently that on the basis of ribosomal ribonucleic acid homologies (4) and deoxyribonucleic acid hybridization (16), the pseudomonads should be reclassified into five groups. As noted above, $P$. anguilliseptica shows strong similarities in whole-cell fatty acid patterns to $P$. aeruginosa and $P$. putida (12) (Table 2), whereas the outer membranes of these species cross-react immunologically with the outer membranes of certain $P$. aeruginosa, $P$. fluorescens, and $P$. putida strains. Thus, we suggest that despite its apparent lack of pigment formation (18), $P$. anguilliseptica may well fit into group I of De Vos, which he calls the authentic pseudomonads.

\section{ACKNOWLEDGMENTS}

This work was supported by research grants from the Natural Sciences and Engineering Research Council (to R.E.W.H.) and the Japanese Ministry of Education (to K.M.). K.N. was supported as a visiting graduate student at the
University of British Columbia by a scholarship from the Japanese Ministry of Education.

\section{LITERATURE CITED}

1. Buchanan, T. M., and J. F. Hildebrand. 1981. Antigenspecific serotyping of Neisseria gonorrhoeae: characterization based upon principal outer membrane protein. Infect. Immun. 32:985-994.

2. Cullen, J., M. C. Phillips, and G. G. Shipley. 1971. The effects of temperature on the composition and physical properties of lipids of $\boldsymbol{P}$. fluorescens. Biochem. J. 125: $733-742$.

3. Dees, S. B., and C. W. Moss. 1975. Cellular fatty acids of Alcaligenes and Pseudomonas species isolated from clinical specimens. J. Clin. Microbiol. 1:414-419.

4. De Vos, P. 1980. Intrageneric and intergeneric similarities of ribosomal RNA cistrons of the genus Pseudomonas and the implications for taxonomy. Antonie van Leeuwenhoek J. Microbiol. Serol, 46:96.

5. Hancock, I. C., and P. M. Meadow. 1969. The extractable lipids of Pseudomonas aeruginosa. Biochim. Biophys. Acta 187:366-378.

6. Hancock, R. E. W., and A. M. Carey. 1979. The outer membrane of Pseudomonas aeruginosa: heat- and $\beta$ mercaptoethanol-modifiable proteins. J. Bacteriol. 140:902-910.

7. Hancock, R. E. W., and H. Nikaido. 1978. Outer membranes of gram-negative bacteria. XIX. Isolation from Pseudomonas aeruginosa and use in reconstitution and definition of the outer membrane permeability barrier. J. Bacteriol. 136:381-390.

8. Hancock, R. E. W., A. A. Wieczorek, L. M. Mutharia, and K. Poole. 1982. Monoclonal antibodies against Pseudomonas aeruginosa outer membrane antigens. Isolation and characterization. Infect. Immun. 37:166-171.

9. Hofstra, H., and J. Dankert. 1980. Major outer membrane proteins: common antigens in Enterobacteriaceae species. J. Gen. Microbiol. 119:123-131.

10. Kaltenbach, C. M., C. W. Moss, and R. E. Weaver. 1975. Cultural and biochemical characteristics and fatty acid composition of Pseudomonas diminuta and Pseudomonas vesiculare. J. Clin. Microbiol. 1:339-344.

11. Kropinski, A. M., J. Kuzio, B. L. Angus, and R. E. W. Hancock. 1982. Chemical and chromatographic analysis of lipopolysaccharide from an antibiotic-supersusceptible mutant of Pseudomonas aeruginosa. Antimicrob. Agents Chemother. 21:310-319.

12. Moss, C. W., S. B. Samuels, and R. E. Weaver. 1972. Cellular fatty acid composition of selected Pseudomonas species. Appl. Microbiol. 24:596-598.

13. Muroga, K. 1978. Red spot disease of eels. Fish Pathol. 13:35-39.

14. Nakai, T., K. Muroga, and H. Wakabayashi. 1980. Serological properties of Pseudomonas anguilliseptica in agglutination. Bull. Jpn. Soc. Sci. Fish. 47:699-703.

15. Overbeeke, N., and B. Lugtenberg. 1980. Major outer membrane proteins of Escherichia coli strains of human origin. J. Gen. Microbiol. 121:373-380.

16. Palleroni, N. J., R. Kunisawa, R. Contopoulou, and $\mathbf{M}$. Doudoroff. 1973. Nucleic acid homologies in the genus Pseudomonas. Int. J. Syst. Bacteriol. 23:333-339.

17. Skerman, V. B. D., V. McGowan, and P. H. A. Sneath (ed.). 1980. Approved lists of bacterial names. Int. J. Syst. Bacteriol. 30:225-420.

18. Wakabayashi, H., and S. Egusa. 1972. Characteristics of a Pseudomonas sp. from an epizootic of pond-cultured eels (Anguilla japonica). Bull. Jpn. Soc. Sci. Fish. 38:577-587.

19. Wilkinson, S. G., L. Galbraith, and G. A. Lightfoot. 1973. Cell walls, lipids and lipopolysaccharides of Pseudomonas species. Eur. J. Biochem. 33:158-174. 